Boise State University

ScholarWorks

$12-1-2017$

Expanding Efficiency: Women's Communication in Engineering

Jennifer C. Mallette

Boise State University

This is an Accepted Manuscript of an article published by Routledge an imprint of Taylor \& Francis Group in Engineering Studies on December 2017, available online at: $10.1080 / 19378629.2017 .1397677$ 
This is an author-produced, peer-reviewed version of this article. The final, definitive version of this document can be found online at

Engineering Studies, published by Routledge. Copyright restrictions may apply. doi: 10.1080/19378629.2017.1397677

\title{
Expanding Efficiency: Women's Communication in Engineering
}

\author{
Jennifer C. Mallette \\ Boise State University \\ jennifermallette@boisestate.edu
}

\begin{abstract}
As engineering fields strive to be more inclusive of women, focusing on perceptions of women's work is vital to understanding how women can succeed and the limitations they may face. One area in need of more attention is the connection between communication and women's experiences in engineering. This article examines the gendered nature of writing labor in engineering, focusing on case studies of three women who were able to use writing effectively, yet how communication emerged as a gendered form of labor subject to gendered perceptions. While these women's communication skills led to professional success, their association with writing echoes a historical division, where writing is viewed as less valuable than technical knowledge. This division has the potential to disadvantage women who are asked to take on more writing-related tasks. In addition, their writing and communication is subject to gendered perceptions of being "chatty" or blunt rather than effective or efficient. Articulating these perceptions and attitudes can lead to a breakdown of the binary between writing and technical labor as well as appropriately valuing the contributions women make in engineering through writing.
\end{abstract}

Keywords: gender; communication; feminism; writing; satisficing

\section{Introduction}

During one of my first visits to the civil engineering firm where she worked, Katy commented, "The joke around the office is that I can't write a short report". ${ }^{1}$ As a professional civil engineer who specialized in environmental projects, Katy frequently wrote, composing reports, memos, meeting minutes, and other forms of communication. Katy's writing was one of her strengths, and it was a skill for which she was recognized both within her workplace and by her professional community. In referring to her writing, she talked at length about efficiency and conciseness, and she expressed frustration with engineers who could not communicate efficiently or effectively, central concepts that not only defined her own writing but would also recur throughout our work together. However, Katy-and her coworkers-also seemed to believe that the writing she so carefully crafted was often more than what was necessary, both in terms of length and energy spent.

Emma, a biological engineering student, struggled with the same notion of concise, efficient prose that is typical of engineering. While she called herself a "creative technical writer," she also acknowledged that "I have such a hard time making my statements concise and explaining in detail what exactly is going on in my head in that moment, you know? [...] I don't want it to be like a huge confused mess." ${ }^{2}$ Emma's desire to write clearly while maintaining a connection to her creative side often put her at odds with the engineering discourse she was acquiring. As a student actively developing proficiency in engineering discourse, Emma was in the process of forming her identity as an engineer, an identity that occasionally conflicted with other elements of her experience. She sought to reconcile what she saw as conflicting approaches by shifting her identity as a writer to align more with the demands of engineering communication, though it came with a sense of loss.

As a tenured industrial engineering professor, Christine's professional identity as a writer was rooted in being concise, yet detailed. She remarked on her tendency to offer more detail in her writing: "It's very important to me that someone can recreate what I'm doing. [...] My husband writes a lot of papers and [...] he uses the minimum amount of words,

\footnotetext{
${ }^{1} 1$ November 2013.
}

${ }^{2} 16$ December 2014. 
This is an author-produced, peer-reviewed version of this article. The final, definitive version of this document can be found online at Engineering Studies, published by Routledge. Copyright restrictions may apply. doi: 10.1080/19378629.2017.1397677

and it's not that they're not accurate and sufficient."3 She explained that her preference is always to add more detail to ensure the readers have the needed information. She asserted, however, that while her male peers write sufficiently and accurately, her desire for more detail and description was perhaps one way her writing differed from theirs. This comparison between her writing and her spouse's-also an industrial engineering professor at the same institutionhints at how she believed she wrote in distinct ways related to her sex.

These stories capture a fleeting glimpse of how these women wrote as engineers and crafted an identity within that disciplinary framework. They also show how both writing and identity were rooted in their experiences as women in engineering. Katy, Emma, and Christine each understood writing in engineering as linked to her experience as a woman striving to be successful in a male-dominated field. These scenes illustrate a sense of conflict over how their writing might be compared to the men they worked alongside in terms of length, style, or description. And while these women identified as strong writers and used writing to attain professional recognition, the association of their professional identities with writing as well as the perceptions of others demonstrate the challenges they faced in being accepted fully as insiders.

In other words, Katy, Christine, and Emma's sex and gendered experiences in the context of writing and communication potentially created barriers to their full membership into their engineering communities of practice. Their position as women (their sex) affected their interactions in school and/or in the workplace because of how they were perceived by others in those settings, and their identities as women (their gender) were part of their professional interactions, including their writing. In addition to being women in male-dominated fields, their identities as writers in a field where ineffective communication is both a stereotype and a recognized problem placed them outside the accepted norm. This article examines their writing through the lens of gender, exploring the ways these three women accomplished their professional goals despite the conflicts and assumptions they faced because of their gender identity and their experiences as women in engineering (their gendered experiences).

Research on perceptions of women in STEM fields illustrates that these women may be consciously or unconsciously responding to notions of what it means to be a woman in a typically masculine sphere. Cultural stereotypes about masculine and feminine forms of communication set up expectations that where men are direct, logical, and concisecommunicative styles valued within engineering communities of practice-women will be indirect, emotional, and expansive. ${ }^{4}$ Yet women also are often view themselves as stronger writers and communicators, as do their peers and instructors. ${ }^{5}$ Haswell and Haswell's study on gender and reader's perceptions, for instance, revealed a "pro-female bias" in responses to student writing, where reviewers rate texts that they perceive to be written by women more highly. ${ }^{6}$ Women are also connected to writing activity in STEM disciplines. Historically in engineering settings, women were denied access to field work and other spheres where "real" engineering work occurred, yet they were able to be involved with the communication of technical information. ${ }^{7}$ In the past, technical writing has been a space where women are accepted and able to contribute. ${ }^{8}$ However, it was also viewed as a "ghetto" women were forced into instead of contributing to the masculine space that engineering embodied—and continues to embody, albeit more subtly, today. ${ }^{9}$

Edward Malone's research into the history of technical communication examines the obscuring of women's contributions to the professionalization of technical communication to downplay what some members saw as the feminization of the field. He argues:

Long before World War II, technical writing and editing were niches of women's work within technical and scientific fields. The emergence of the modern field of technical communication in World War II and the postwar years continued this tradition even as male practitioners and academics sought to professionalize the field. ${ }^{10}$

\footnotetext{
${ }^{3} 20$ January 2015.

${ }^{4}$ Annas, “Style as Politics,” 2003; Flynn, “Gender and Reading,” 1983; Flynn, “Composing as a Woman,” 1988; Hiatt, “The Feminine Style,” 2003; Haswell and Haswell, "Gendership and the Miswriting of Students, 1995, p. 233.

${ }^{5}$ Charney, Newman, and Palmquist, "I'm Just No Good at Writing," 1995, pp. 314-315; Haswell and Haswell “Gendership and the Miswriting of Students," 1995, p. 233.

${ }^{6}$ Haswell and Haswell, "Gender Bias and Critique of Student Writing,” 1996, p. 60.

${ }^{7}$ Malone “Chrysler’s Most Beautiful Engineer,” 2010, pp. 145-146; Rossiter, Women Scientists in America, 1995, pp. 261-264.

${ }^{8}$ Connors, “The Rise of Technical Writing Instruction in America," 1982; Malone "Chrysler’s Most Beautiful Engineer," 2010; Malone "Women Organizers of the First Professional Associations in Technical Communication," 2015; Richie and Boardman, "Feminism in Composition,” 2003.

${ }^{9}$ Malone, “Chrysler’s Most Beautiful Engineer,” 2010, p. 146.

${ }^{10}$ Malone, “Chrysler’s Most Beautiful Engineer,” 2010, p. 177.
} 
This is an author-produced, peer-reviewed version of this article. The final, definitive version of this document can be found online at Engineering Studies, published by Routledge. Copyright restrictions may apply. doi: 10.1080/19378629.2017.1397677

Women were permitted to participate in science settings as writers and editors because writing was perceived as labor appropriate for women. Their work as writers was also used as an exclusionary tactic to prevent women's full participation in the creation of scientific knowledge, and even their contributions to technical communication were obscured. ${ }^{11}$ Part of these attitudes emerge from the position of technical communication in relation to STEM fields, where communication has historically been seen as secondary to the work of scientists. For instance, Bernadette Longo examines the development of technical writing part of "an economy of technical knowledge and power." ${ }^{2}$ She argues that writing became a task for lower-paid writers who could take care of the labor of communicating the knowledge and technology generated by the higher-paid (and overwhelmingly male) engineers. Technical communication was thus viewed as a "spurious coin" to the real currency of scientific knowledge, ${ }^{13}$ a perspective that allowed engineers to see writing and engineering labor as separate hierarchical practices. The view that technical labor is superior to writing because writing can be done by anyone, even non-engineers (and particularly women), is part of the culture of engineering, and one that has potentially dangerous implications for engineering women who identify as strong communicators.

Despite these historical realities, relatively few studies have examined sex differences in engineers' self-identification as writers, including how gendered experiences affect women's participation in engineering communities of practices. For one, women are often not included in research examining engineering communication. In some cases, women were unavailable to participate rather than intentionally excluded. ${ }^{14}$ Given the prevalence of men in engineering fields, finding willing participants can be a struggle. However, in other studies, women were not included, yet their absence was not addressed, ${ }^{15}$ or no attention was called to their presence or underrepresentation. ${ }^{16}$ More recent studies have included women more overtly, although gender itself is not the primary focus. ${ }^{17}$ In addition, STEM fields have a long history of obscuring or misattributing the contributions of women to scientific research or marginalizing women altogether, sending the message that "women and science do not appear to go together." 18 Given women's continued underrepresentation in engineering, studies focusing primarily on women's communication in engineering are needed not only to call attention to the struggles women face, but also to demonstrate that women are active participants in the field.

While more research examining women and engineering communication is needed, communication scholars have explored the connections between gendered forms of discourse and how they affect women in collaborative settings typical of engineering learning environments. For example, Joanna Wolfe and Kara Poe Alexander examine how gendered speech styles affect communication and collaboration in a classroom setting, finding that men often assume the role of "computer expert" and shut down debates over choices and control the end product.19 Wolfe and Elizabeth Powell explore the impacts of gender-typical speech acts in engineering team settings, where speech acts associated with women, such as prefacing statements with "I think," are seen as weaker and less effective.20 In fact, women are frequently advised to change their speech to communicate more clearly, most recently by a book focused on helping women overcome the bias they face in the workplace by changing how they communicate. 21 Thus, research demonstrates that although women are more likely to identify as writers and be seen as exemplary communicators, gendered communication styles may interfere with their ability to be fully accepted or to succeed. If writing in engineering is viewed as a skill at which women excel, yet writing has historically been a way of marginalizing women from producing engineering labor in the most valued forms, how does writing affect women in engineering fields today? For women who see themselves as skilled researchers and designers as well as communicators, does writing facilitate or inhibit their success as engineers?

\footnotetext{
${ }^{11}$ Malone, "Women Organizers of the First Professional Associations in Technical Communication,” 2015, p. 121.

${ }^{12}$ Longo, Spurious Coin, 2000, p. 8.

${ }^{13}$ Longo, Spurious Coin, 2000.

${ }^{14}$ Leydens, “Novice and Insider Perspectives on Academic and Workplace Writing,” 2008, p. 246.

${ }^{15}$ Winsor, Writing Like an Engineer, 1996.

${ }^{16}$ Winsor, Writing Power, 2003.

${ }^{17}$ Poe, Learner, and Craig, Learning to Communicate in Science and Engineering, 2010.

${ }^{18}$ Watts, Women in Science, 2007, p. 1.

${ }^{19}$ Wolfe and Alexander, “The Computer Expert in Mixed-Gendered Collaborative Writing Groups,” 2005, pp. 151.

${ }^{20}$ Wolfe and Powell, "Biases in Interpersonal Communication," 2009, pp. 10-11.

${ }^{21}$ Kramer and Harris, Breaking Through Bias, 2016.
} 
This is an author-produced, peer-reviewed version of this article. The final, definitive version of this document can be found online at Engineering Studies, published by Routledge. Copyright restrictions may apply. doi: 10.1080/19378629.2017.1397677

\section{Method}

With these conflicts and questions in mind, I set out to examine the connections between women's gendered experiences and the writing they produce within engineering contexts. Designed using an ethnographically informed case study approach, the study focused on three women who were highly capable engineers and writers: Katy, Christine, and Emma.

- Katy and I met while she was pursuing a master's degree in civil engineering. At the time of the study, she had been employed for 10 years by a mid-sized civil engineering firm. Her focus was on environmental engineering projects, and she had been the design engineer on a wastewater treatment project, which was nearing completion during our work together. Katy was deeply interested in writing, and even though she was willing to assert that she was a strong communicator, she also sought to learn more about writing. Her curiosity about writing and her desire to improve her communication skills was one of the driving forces of this study.

- Christine, an industrial engineering researcher and full professor, and I were connected through a mutual friend and colleague, another engineering professor interested in effective engineering communication. Christine frequently collaborated with peers at her institution and graduate students on research and writing. She also was responsible for administrative and marketing communication as part of her responsibilities as a dean and director of a research center. While Christine was less forthcoming about her writing and experiences as a woman in engineering than the other participants, as she and I engaged in conversations about teaching and authorship, she demonstrated her interest in writing, her commitment to supporting her students' writing education, and her focus on mentoring other women in the field.

- Emma was a biological engineering undergraduate student engaged with community engineering projects. We met when I gave a presentation on writing for first generation college students, and I noticed her interest and engagement with the material. She agreed to participate when I reached out to her. Emma chose engineering because of the ways her degree would allow her to contribute to community building. Her goals included potentially pursuing a doctorate, volunteering for the Peace Corps, and becoming an educator, or someone who advocates for sustainable actions and sustainable building. She was also eager to learn more about writing, and our conversations often veered into discussions about approaches for effective communication. She was also conscious about seeking out mentors to enhance her education in a variety of contexts.

For this study, Katy is the central case and the person who provided the most information-including interviews with her co-workers-while Christine and Emma's experiences offer data similar to or in contrast with Katy's experience.

Case studies use small sample sizes in order to explore questions that require awareness of context and more depth than data focused on a range of participants can provide, though it limits generalization of findings. ${ }^{22}$ The research methodology used here included a series of interviews with each participant as well as the collection of writing samples to gain a sense of their experiences as active engineering communicators, their writing process, and how they approached the act of writing. ${ }^{23}$ I was also able to observe two of the participants—Katy and Emma—as they generated written texts. These observations allowed me to directly observe their writing in process and ask them questions about their approaches and the material under construction. The study concluded with a final interview that focused on each participant's gendered experiences in engineering, though their experiences as women in engineering were discussed throughout the study. As a member of the same institution, I was familiar with the university culture within which both Emma and Christine worked. I gained an ethnographic perspective of Katy's workplace by observing her in that setting and conducting interviews with her coworkers, even accompanying her to a meeting at the wastewater treatment plant project site in another city. All together, these forms of data collection allowed me to get a clearer sense of what it meant for these three individuals to write as both engineers and women. While the small number of participants prevents generalization of the data, these women's experiences illustrate connections between engineering

\footnotetext{
${ }^{22}$ Yin, Case Study Research, 2009; Yin, Applications of Case Study Research, 2012.

${ }^{23}$ This study received Institutional Review Board approval from the researcher's former and current institutions.
} 
This is an author-produced, peer-reviewed version of this article. The final, definitive version of this document can be found online at Engineering Studies, published by Routledge. Copyright restrictions may apply. doi: 10.1080/19378629.2017.1397677

practice, identity, and writing. In this article, I examine how these three women used writing to achieve professional goals despite the ways their writing was perceived in particularly gendered ways. I also explore the quandary that writing creates for these women because of their gender, including unfair divisions of labor, unrecognized effort, and perceptions of their writing as gendered, concluding with possible implications for women writers in STEM.

\section{Using Writing to Accomplish Action}

One research question considered the impact writing had on women in engineering. If women are seen as generally stronger communicators thanks to cultural stereotypes of women as more verbally gifted, then theoretically they may have had more opportunities to develop their communication skills and employ them in engineering settings than some of their male peers. For example, one study shows that women may be more likely to enjoy writing than men and view it as more learnable, factors that may have an impact on their academic performance as women tended to earn higher grades in writing courses. ${ }^{24}$ Engineering itself is seen as a field where poor communication is the norm and engineers talk about their own writing as boring or lacking in skill. ${ }^{25}$ Verbal and written communication may provide an avenue for success, since the stereotype of engineers as poor communicators is less likely to hold true for these women, and thus communication becomes a readily available tool that could offer an edge in engineering settings. In addition, research suggests that high grades in first year writing courses are correlated with retention in STEM programs and success in STEM courses. ${ }^{26}$

Although the present study's sample size is too small to generalize across engineering communities of practice, one commonality Katy, Christine, and Emma shared is how they used writing to accomplish their professional or academic goals. Two characteristics their writing shared was their focus on audience through reader-centered writing and their use of detail to meet their readers' needs. These two characteristics emerged from each participant's reluctance to satisfice, ${ }^{27}$ or do the bare minimum to get the job done in ways that might be perceived as efficient yet ignore a reader's needs. These traits allowed them to use writing to pursue success and be perceived as skilled in environments where their sex and gender identity might put them at a disadvantage.

In particular, Katy strongly believed that she was a stronger and more careful writing than her coworkers. When asked to comment on the influence of her gender identity on writing, she responded:

Oh, hell. I really have no idea, quite honestly. I feel like I have a strong personality in general, but I don't think that's gender-related. And I think that strong personality makes me want to do a good job [...] whether it's gender-related or not, I tend to do a better job than some of my compatriots for some reason. I think sometimes, I don't know if this is typical or not, for instance, [some people] will put a report together, and it's just good enough. And they won't agonize over it, and they'll just get it out, and it'll be whatever it is. But I feel like I really internalize things and want to make it squeaky clean and beautiful. And I'd hate to do something wrong and be called out or embarrassed because they didn't do something great. So that's just kind of my personality difference that makes the whole experience different for me, and I don't know if that's related to gender or not. I mean, I remember being told as a kid that girls are good at writing and men are good at math and math will be harder for you. I remember that. And I remember halfway still believing it [...] and then I realized, no it's harder for men too. Or some people are just inclined to it. I don't necessarily think that men are inclined to math and women are inclined to writing. ${ }^{28}$

Katy attributed her focus on writing success as part of her personality—she wanted to be successful in all areas of engineering practice-but she also was aware that she had received subtle messages about how women might struggle in math but be effective communicators. Her experience as a woman in engineering meant pushing against these stereotypes and not settling for work that had the potential to mark her as less competent or skilled.

\footnotetext{
${ }^{24}$ Charney, Newman and Palmquist, “I’m No Good at Writing,” 1995, pp. 314-315.

${ }^{25}$ Winsor, Writing Like an Engineer, 1996, p. 88.

${ }^{26}$ Callahan and Belcheir, “Testing Our Assumptions,” 2017, pp. 171-172.

${ }^{27}$ Simon, The Sciences of the Artificial, 1969, pp. 64-65.

${ }^{28} 17$ December 2014.
} 
This is an author-produced, peer-reviewed version of this article. The final, definitive version of this document can be found online at Engineering Studies, published by Routledge. Copyright restrictions may apply. doi: 10.1080/19378629.2017.1397677

For Katy, successful writing thus became a way to demonstrate her competence as a professional. While she struggled with the notion of how much her attention to writing was connected to her gender-or how much was just her personality—she understood that her approach differed drastically from her peers'. When asked if the stakes were higher for her as a woman in engineering, she responded:

I feel that this is a little bit of a male stereotype, where they tend to divert blame a little bit, where they can't internalize it as "I wrote that report or I designed that facility, and I fucked it up, and I take full responsibility for that." So a lot of times they're "oh, there were these certain circumstances," like making some sort of rationalization for it. And sometimes, maybe it's right. Maybe it's they [the company] threw you in the deep end of the pool and they should have trained you. But I think I would be like "oh, it’s all my fault!” I've had those moments actually, where I'm "oh! I've destroyed everything!” and they're like "calm down. It’s fine.” [...] Where I probably don't do the converse, where something goes right and I pat myself on the back for it. ${ }^{29}$

Despite her confidence as a writer and her assertion that she is better than most of her coworkers, Katy struggles to celebrate her successes. She is comfortable and confident in her ability to make engineering decisions that benefit the client and to communicate those decisions in writing, yet she also took on the burden of blame if something went wrong. In comparing herself to her peers, she noted that they may not produce as thorough of a report, nor will they fully accept the blame if a mistake occurs because they were not thorough. This pressure to demonstrate competence, Katy noted, is partially a product of her own personality and approach to the world as a high achiever but may also be symptomatic of the pressures women in male-dominated fields face to perform better than average. ${ }^{30}$ Katy commented on this dilemma:

I think I'm harder on myself than other people would be on me. That's been my feeling is when I have issues, I generally have small panic attacks about my ineptitude, which I'm not sure the average male would do. [...] and maybe this is partly my personality and partly gender roles too, the asking of questions and trying not to fuck up in the first place where I'd be more likely to say "teach me, tell me.” And not seeing it as a weakness that I don't already know these things versus people who maybe don't know to ask the question. Or feel like I exhibit doubt or ask questions, they won't think I'm as smart. There's nothing at risk there, they're going to pay you the same. ${ }^{31}$

Because of the pressure to demonstrate competence and her fear of failure, Katy took writing seriously. She was also willing to ask for help and to get feedback from her mentor, who she always asked to look over her writing because she trusted his ability. Early in her career, she used his feedback to learn the genres and stylistic conventions of successful engineering communication. She remarked that he gave her less feedback at this point in her career, partly because she is a better writer. ${ }^{32}$

Even while expressing anxiety and feeling the pressure to perform above average, Katy saw herself as more competent and skilled than many of her peers. Katy's belief in her own success is backed up both with praise from her coworkers and supervisors and through professional accolades from state agencies and professional organizations. Likewise, Christine and Emma were praised and rewarded for their writing ability. When I asked Christine to rate her writing in comparison to peers in her field, she replied:

Normally, my papers come back [from reviewers] and say it’s very well written. So I would saynow sometimes there are suggestions, but as long as I have been actively involved in the revising, and especially if it was a student-led paper, then I would say probably on average, my writing is better. But some of that is related to experience. I'm sure my writing is better now than it was before. My undergraduate education involved writing. We had to take a set of humanities, and I chose to take English literature courses that had a writing component. So I think I elected to do more writing. I even had writing in high school. So I'm somewhat on the edge of having a well-rounded approach to life, as opposed to just being very interested in the technical side or the science, so I think I've had more instruction probably related to writing. And in my undergraduate program, we took

\footnotetext{
${ }^{29} 17$ December 2014.

${ }^{30}$ Bix, Girls Coming to Tech!, 2013; Layne, Women in Engineering, 2009.

31 17 December 2014.

3217 December 2014.
} 
This is an author-produced, peer-reviewed version of this article. The final, definitive version of this document can be found online at Engineering Studies, published by Routledge. Copyright restrictions may apply. doi: 10.1080/19378629.2017.1397677

technical writing and communication. So I have had some training. I think my [dissertation] adviser is a pretty clear writer, a very structured writer, so from my side, from the engineering side from the types of papers that I write, I would say I'm probably above average. ${ }^{33}$

Like Katy, Christine was modest in praising her own ability, saying that it was "above average" rather than using stronger terms. In addition, she attributed her skill to experience, education, and mentorship and somewhat downplayed her own hard work and mastery of writing in the field. However, Christine uses reviewer comments and publication as a metric of success, which matches how writing is used in her field-publications and grant funding show a productive, capable researcher and are the basis of receiving tenure and being promoted at a research institution. Christine commented that she also has won awards for her writing. ${ }^{34}$ These metrics are indicative of her ability to write in ways that the field recognizes as exceptional, and as such, she is able to communicate her research findings to a broader audience and see the impacts of her work.

As a student, Emma's metrics for success depended heavily on grades in her engineering coursework and comments she received on her writing. For instance, she remarked that she realized she was getting comments on her responses to questions in the freshman engineering seminar where other students did not:

Some people in response to an engineering question in GNEG [General Engineering] gave maybe two sentences, you know, and I would give like two paragraphs to explain, go into depth and everything. Like my reflective writing, I always got back "good job" on the grading. So on Blackboard, you know how you can pull it up and you can see your letter grade. There would be a note, and I'd open it up and it would say good job. So I asked other people, and no one had gotten good job. So I felt like I wrote better, I guess, I don't know. ${ }^{35}$

In addition to writing for her engineering courses, Emma also had experience writing as an intern producing summaries of articles for a researcher in a lab and as a member of a student organization that received grant funding to build a rainwater catchment system for a local community garden. She also applied frequently to scholarships.

I feel like based off of the things I've accomplished I should be a strong writer because I've gotten so many scholarships, like almost every scholarship I've applied to I've gotten, so like probably $80 \%$ of the scholarships I've applied to, I've gotten, and I've applied to a lot of scholarships, and grants. And also with my African American history class, I feel like, we only had that 50 minute time slot to write our essays in class, so like in our quizzes, we only had that time slot, and I made a really good grade on each of the quizzes, but he wasn't really looking for grammar, but I feel like I was still able to get my point across. And I'm not a great public speaker, but sometimes that reflects in my writing, and that always makes me nervous that comes out in my writing. ${ }^{36}$

Despite her frequent writing, receiving exemptions for both first year writing courses, and the academic and personal success she gained through writing, Emma also was hesitant to promote her writing ability, remarking, "I feel like I can definitely improve with my writing. So, I would probably say that I'm $60 \%$ confident with my writing." 37 The confidence she has stems from her awareness that she puts a lot of work into her writing, seeking out feedback from a variety of sources, including peers, professors, and the university writing center. When asked to rate herself in comparison to her peers, friends, and classmates, Emma remarked:

In quality? Depends on the peers. I have one who's like double majoring in engineering and English and is just amazing. I feel like it's average, at least around my peers. Now my classmates, though, again I think I go into more detail than my classmates do. ${ }^{38}$

Here, she distinguishes between her friends, who are also high achievers, and her classmates, who she sees herself stronger than, partly because she is willing to go into more detail than the average student.

In response to why she thought she was willing to go into more detail, Emma called on her experiences reading and writing as a way that sets her apart from others:

\footnotetext{
${ }^{33} 26$ January 2015.

3423 June 2014.

35 August 2014.

${ }^{36} 25$ August 2014.

${ }^{37} 25$ August 2014.

${ }^{38} 25$ August 2014.
} 
This is an author-produced, peer-reviewed version of this article. The final, definitive version of this document can be found online at Engineering Studies, published by Routledge. Copyright restrictions may apply. doi: 10.1080/19378629.2017.1397677

Because I read articles and essays that have been written from such different viewpoints and walks of life that I feel like, because I even read blogs sometimes online just to see how people communicate. That fascinates me, to see how people communicate outside of what grammar has taught us to be correct. So I feel like because I read so many different viewpoints that I'm able to write from so many different viewpoints, so write in a different manner that what might be normal. So I like to push the boundaries a little bit. ${ }^{39}$

However, like Katy and Christine, Emma also may be reluctant to promote her writing skill due to social constraints as well as the knowledge that she has more she can learn because of the highly competent communicators she works with or for.

Despite their occasionally modest assessments of their own writing ability, Katy, Christine, and Emma are successful by external measures and are able to accomplish their goals through writing. To be successful, these three women shared two writing tendencies: audience awareness and a willingness to go into more detail, which is a result of their reader-centered approach. These two tendencies emerge from a strong work ethic that prevented each participant from satisficing in their writing. Satisficing is a term used in economics to characterize sufficient approaches—choices that satisfy base requirements - that are not ideal. ${ }^{40}$ In an engineering context, a writer might satisfice by writing just enough to meet the requirements, but they may not give detail useful to some readers nor would they revise to make sure the style of the report is accessible to non-engineers. In terms of a report, a consulting engineer who satisfices might finish the work at the last minute and potentially use language from other reports without assessing the audience's or client's particular needs. For an academic engineer, satisficing might mean giving less description or using a theoretical example that is not fully rooted in the real world. And for a student, satisficing might mean working at the last minute and not revising writing with feedback from available resources. However, Katy, Christine, and Emma all pushed against pressures to satisfice in a number of ways, including spending significant time drafting and revising and offering detail that goes beyond the minimum requirements.

\section{Reader-Centered Writing}

One element of this refusal to satisfice that leads to success is each participants' audience awareness or readercentered approach to writing that sets them apart from many of their male peers. Drawn from writing studies research, reader-centered writing allows the writer to focus on the audience's needs and work to meet them, often focusing on long-term impacts rather than only short-term accomplishments. ${ }^{41}$ For example, Katy often invoked what the reader needed as the basis for her writing choices. She was quick to acknowledge that communicating to readers-persuading an audience of engineers and non-engineers alike-was a key part of her job:

Because it may just take you a small amount of time to come to a design conclusion, but then you have to put that in writing for, say, a city council or a commission-you have to explain the whole process to them, which might be really easy to you, but you've got to put it in a layman's terms and that can take a very long time if you're starting from scratch. ${ }^{42}$

Along with her comments above, Katy here demonstrates that she is aware that while designing may be what is recognized as engineering labor, writing is where the engineer then persuades specialist and non-specialist readers that the design choices are sound. By focusing on the reader, especially when the audience is at least partially composed of non-technical members, an engineer can better persuade them to agree with her recommendations. Katy thus explains that the writing and persuading ultimately involves more of an engineer's time and labor rather than the design work itself.

One instance of her reader-centered approach emerged in Katy's attention to meeting minutes. Successful minutes should summarize key information concisely to produce future action, meaning they should focus on what readers need to know. ${ }^{43}$ However, in Katy's firm, minutes were produced initially as transcripts, then reviewed and revised by the project engineers. Thus, the minutes were often filled with conversations unrelated to the topic (jokes, long tangents, etc.) because they were a nearly verbatim transcription of the meeting instead of a summary of key discussions. When Katy did not review the minutes one month, they were sent out unrevised, a long document that

\footnotetext{
${ }^{39} 25$ August 2014.

${ }^{40}$ Simon, The Sciences of the Artificial, 1969, pp. 64-65.

${ }^{41}$ Flower, "Writer-Based Prose,” 1979; Sommers, "Revision Strategies of Student Writers and Experienced Adult Writers,” 1980.

427 November 2013.

${ }^{43}$ Wolfe, “Meeting Minutes as a Rhetorical Genre,” 2006, pp. 358-360.
} 
This is an author-produced, peer-reviewed version of this article. The final, definitive version of this document can be found online at Engineering Studies, published by Routledge. Copyright restrictions may apply. doi: 10.1080/19378629.2017.1397677

would likely not be read. While it seems more efficient to just send out the minutes this way-after all, most of the recipients attended the meeting-Katy recognized that the minutes would never be read or used if they were not drafted and revised into something shorter and clearer. Over the course of the project, she took over drafting the minutes so that she was creating them herself from the recording rather than revising the transcript. This approach meant that she could make the minutes shorter, usually around 6 pages instead of more than 20, which meant the reader would be able to find needed information. In addition, she added section headers that allow the reader to skim and locate information easily. Finally, in her most reader-centered change, Katy added in action items after each section to provide a bulleted summary of crucial information. These changes meant that the minutes were no longer reflecting the past but instead allowed Katy to focus on future action, the tasks that needed to occur before the next meeting.

While Katy would rather spend her time doing tasks other than creating the minutes, she refused to satisfice. Creating the minutes was time consuming, and they were not design work, the labor recognized as valuable by her profession. The most efficient course of action seemed to be to let the administrative assistant create the transcript, satisficing because the result would be good enough for the requirements. The engineer's time could be spent in other activities, particularly more typical engineering work. However, those minutes would be inefficient in that no one would read them, and the transcript-style minutes would likely be filed or ignored entirely. With Katy's revisions and addition of action items, the minutes became more efficient because the readers were able to use the minutes, Katy did not waste time on reviewing and revising a verbose transcript, and Katy's supervisor used the minutes to set the next month's agenda. In other words, the minutes took more energy to create but had a greater impact in their use. Thus for Katy, efficiency always accounts for the user, not simply the time expended and reader-centered meeting minutes are more likely to accomplish action. Because she focused on what the readers would need from the minutes, the minutes became a reflection of her competence and demonstrated her company's professionalism. ${ }^{44}$

Katy's use of reader-centered writing offers an understanding of efficiency that Erin Frost argues should be "focused primarily on effects on human lives and secondarily on speed and energy." ${ }^{45}$ In other words, each writer considers the reader's energy expenditures, not just the writer's. By refusing to satisfice, each of these women also embraced an alternate definition of what constitutes efficiency in engineering settings: efficiency as not solely defined by energy expended but by results that account for a diverse range of audiences, as reimagined by Frost. ${ }^{46}$ Frost argues for "apparent feminism" as a methodological approach to technical communication to reexamine ideologies and disciplinary terms, "requiring that we interrogate the invisible underpinnings of these terms to make their values more apparent." ${ }^{47}$ Efficiency, a major value in engineering communication, is one term worth reexamining to understand how these three women resist and redefine what constitutes efficient labor. When viewed as a reframing of efficiency, Katy, Christine, and Emma's approaches reveal how writing demonstrates their ability and professional capacity.

Like Katy, Christine kept her audience in mind as she writes, engaging in a reader-focused form of efficiency. The opening scene is one example of how aware she is of a reader's needs and thus her obligation to offer more detail than her male peers tended to. Another way she engaged in reader-centered writing is in her use of examples:

I tend to put practical examples, you know, some kind of case study that's rooted in a real example. So I'm not just going to say "imagine there are five barges and that two of them are disrupted and it lasts for two hours and this is what you get." I will say "a windstorm caused a failure of the bridge over the [X] system, it was down 24 hours," like I will pull up that data and use it. I think that's important in putting the context and convince anyone that it could be used for something realistic. ${ }^{48}$

Christine's approach focused on the story she needed to tell. In a sense, she viewed her task as making a coherent narrative that anyone can follow and that also convinced the readers. While a theoretical example might fit the scenario or data more neatly, she believed that by focusing on an actual event, she could provide a more realistic application and context for the arguments she wants to make, having a greater impact on both researchers and practitioners. In viewing academic publications as a form of storytelling, Christine engages in an alternate view of efficiency, one that allows readers to more quickly understand her findings:

\footnotetext{
${ }^{44}$ For a fuller discussion, see Mallette, "Writing and Retention in Engineering," 2017.

${ }^{45}$ Frost, "Apparent Feminism as a Methodology for Technical Communication and Rhetoric," 2016, p. 19.

${ }^{46}$ Frost, "Apparent Feminism as a Methodology for Technical Communication and Rhetoric," 2016.

${ }^{47}$ Frost, “Apparent Feminism as a Methodology for Technical Communication and Rhetoric,” 2016, p. 16.

4820 January 2015.
} 
This is an author-produced, peer-reviewed version of this article. The final, definitive version of this document can be found online at Engineering Studies, published by Routledge. Copyright restrictions may apply. doi: 10.1080/19378629.2017.1397677

I'm very systematic in the way that I write, and when I'll put proposals together, I'll get things written by twenty people, and I'll take all of that and put it into an organized story that sells and try to figure out the common themes and what are the common projects that we're going to carve out of this. ${ }^{49}$

She reiterated that goal: “Oftentimes I'm going from multiple documents and trying to put it into something that is a single story that someone outside can understand." ${ }^{50}$ Christine's writing is informed by her knowledge that efficiency is more than the relationship between energy expended and outcomes. Instead, her writing is efficient because it emphasizes quality and reader understanding. ${ }^{51}$ Taking threads of ideas from multiple sources to craft a coherent, compelling narrative that appeals to a given audience allowed Christine to write successfully as an engineer and to thus be viewed as successful by her number of publications.

Although Emma was still in the process of learning to write as an engineer during this study, she also demonstrated an ability to focus on her readers and allow them to access information efficiently. For instance, she described the struggle she faced in creating a presentation out of technical, jargon-heavy material. As Emma was on her way to the conference and still struggling with the presentation, her mother asked her why she was using heavily technical language, reminding Emma that her audience would not be other engineers. Her mom added, "Say it how you would say it to me. When you explain the project to me, I understand it and I like it." 52 For Emma, this was a major turning point in thinking about how to accommodate information and communicate effectively based on that audience's needs: "And so I learned to speak about my project in a way that's not technical, but in a way that's still the facts and engages with the community. Because that's who we're talking to, the community, not other scientists." 53 In accounting for her audience, Emma is more likely to successfully communicate her message and accomplish her goals.

This audience awareness would serve her well in other writing settings as Emma learned to be an effective communicator, whether she was writing for a nonspecialist or a technical reader. As Frost argues, speaking to a broader, more diverse audience can also be efficient because "increased audience represents a significantly greater result." ${ }^{54}$ For instance, one document Emma wrote during this study was a project update required by the grant her student organization had received. She talked about how this update was different than previous ones because "I already caught them, I already got them excited, and so I'm just telling them what happened now. [I] didn't have that pressure to make them feel like they were happy to have chosen us, now we have evidence that we actually did this." 55 As I observed her creating this update, she would stop to think about what she should say, bringing up the reader and what they likely needed. For instance, Emma puzzled over how to address the reader:

I'm trying not to come off offensively? Because I'm trying to decide, how do you write down someone who's not in the student body, like someone who is a community outsider-I don't want to call her an outsider though, does that make sense? Because we had community support, and I want to make sure that's in there, but not in an offensive way. ${ }^{56}$

Later, she addressed her tone again in the context of the audience, as she discussed why she was opting for what she called a "diary" or "reflective" approach:

And I feel like with our project, it's not just tactical, it's really engaged with the community, so I do want to come off a little bit more, like I do like the diary feeling, so I don't want to take that way because I feel like our main goal with this rainwater catchment system is not only to make tricycle water sustainable, but it's also to bring the community together and teach people how they can have an impact on their environment, on their water savings and stuff like that. So I don't want to come off, I don't want it to be all tactical, but I do want to make it a little bit more professional. ${ }^{57}$

\footnotetext{
4920 January 2015, emphasis added.

5020 January 2015.

${ }^{51}$ Frost, “Apparent Feminism as a Methodology for Technical Communication and Rhetoric,” 2016, p. 18.

5219 September 2014.

5319 September 2014.

${ }^{54}$ Frost, “Apparent Feminism as a Methodology for Technical Communication and Rhetoric,” 2016, p. 17.

5516 December 2014.

${ }^{56} 19$ September 2014.

${ }^{57} 19$ September 2014. While Emma says "tactical,” she may actually mean "technical.”
} 
This is an author-produced, peer-reviewed version of this article. The final, definitive version of this document can be found online at Engineering Studies, published by Routledge. Copyright restrictions may apply. doi: 10.1080/19378629.2017.1397677

While the project update was likely not held to the same standards as work in her courses and definitely not as highstakes as the proposal to earn the grant, Emma still thought carefully about the audience's needs while drafting and revising the document. This attention means she is more likely to communicate clearly and effectively. Even though it takes more time, if the message is received as she intended, Emma's writing is efficient. By learning how to speak to multiple audiences or consider the needs of a nonspecialist audience, Emma is thus learning how to be a more efficient as well as effective communicator.

\section{Use of Detail}

For each of these writers, detail relates to a work ethic that rejects satisficing as an acceptable approach. Because they were focused on their audience's needs, Katy, Christine, and Emma all demonstrated a willingness to go into more detail than some of their male colleagues or coworkers or peers. Their tendency to offer more detail in their writing was driven not only by a sense that their audience needed to know the additional information but also by a refusal to give in to satisficing. In one way or another, each of the participants characterized her approach as writing more than enough in order to better accomplish her goals and meet the audience's needs. Therefore, providing more details and not satisficing or doing "just enough" actually makes their work more efficient—and ultimately, more successful— because it has the potential for greater long-term impact.

Katy and Christine were both aware of their willingness to go into more detail than many of their male peers as well as their focus on the long-term uses of their writing, and others also seemed to notice the use of detail. For instance, Katy's company president remarked, "What I've noticed about her writing is that she almost writes like she's writing a textbook [...]. She goes into a lot of detail, a lot of explanation." ${ }^{58} \mathrm{He}$ also commented that this amount of detail allowed technical and nontechnical readers to each grasp the knowledge Katy conveyed. And Katy herself keeps those diverse readers at the forefront of her mind as she generates text because she is aware of the sharp distinctions in knowledge and the varied needs those readers bring to a report. In using more detail, Katy took a long-term view of her writing, understanding that more detailed explanations make the work useful and efficient beyond the initial audience, since she or another engineer in her firm may use her report as the basis for future work. In fact, she often joked that past Katy was smarter than present Katy when she revisited her own writing because she inevitably saw some idea or concept she had forgotten about but needed to know.

Christine's willingness to go into more detail is also motivated by her reader's needs and an understanding of the longterm uses of her work. As a researcher, she experienced the difficulty of attempting (unsuccessfully) to reconstruct a methodology from someone else's research who did not provide enough information: "I know how painful it is to really try to look in detail into someone's paper and they're missing key components. And it could be something that happened so long ago that you can't go back." ${ }^{59}$ While she could put less information in and still get her research published, Christine understood that other researchers may later need that detail, and she would rather not force them to attempt to unsuccessfully recreate a study with insufficient methodological detail. The detail represents a form of disciplinary efficiency in that she ensured the availability of information for future researchers, ultimately having a greater impact on a number of readers. In addition, by providing more detail, Christine addressed the scientific value of enabling other researches to theoretically replicate her study. Subsequently, it also increaseed the potential impact of her research through more citations, more grant funding, and more attention to her research center.

As an engineering writer in training, Emma also viewed her descriptive writing as a trait that set her apart from others and one similarly linked to a reluctance to satisfice and an alternative view of efficiency. She explained, "I go into much more detail than most people do. Other people are much more concise. I use simple words but more description. Other people use more complicated words so they don't have to use description. Like this word will take the place of these four words.” ${ }^{60}$ Attending to the needs of her audience, Emma not only avoided more technical and potentially confusing language but also generated more content to explain fully. These habits earned her better grades in her engineering courses and were fueled by her desire to make her writing understandable to her readers. She also understood that detail was one way to demonstrate learning to her instructor, illustrating her commitment to learning not just earning better grades:

\footnotetext{
${ }^{58} 18$ February 2014.

${ }^{59} 20$ January 2015.

6016 December 2014.
} 
This is an author-produced, peer-reviewed version of this article. The final, definitive version of this document can be found online at Engineering Studies, published by Routledge. Copyright restrictions may apply. doi: 10.1080/19378629.2017.1397677

And I feel if you explain it, it shows you know the nitty-gritty details of it, and that's important to show your instructor. Because obviously your instructor understands the process, but by you explaining it, you're not only showing the instructor that you understand it completely but you're also writing it again inside your brain, implanting it in there more firmly, so you're learning it better. ${ }^{61}$

Emma was conscious that offering more detail was a way of demonstrating her learning and, more importantly, helped her learn the material better. Offering more detail thus ensured she was more successful in her engineering courses as well as communicating to a range of readers.

For all three of these women, offering more detail was a way to focus on the reader's needs. This use of detail in the pursuit of reader-centered writing also indicates the ways all three women may be expanding their understanding of what can be considered efficient in engineering contexts. By refusing to satisfice, Katy, Christine, and Emma are likely to offer detail that allows their message to be effectively communicated. On the surface, their approach seems to require more time and space, and thus seems less efficient when understanding efficiency as only accounting for energy and time expenditures. Viewing efficiency in a narrow way makes it easy to dismiss the time and energy it takes to write more as inefficient and thus inconsistent with the values of engineering. However, if efficiency is understood as "focused on effects on human lives," 62 as Frost argues, then these women may be engaged in expanding what constitutes efficiency in writing in engineering contexts. If taking more time to attend to the needs of readers means that the writing is more likely to reach the desired outcome, then writing more—offering more detail—makes writing more efficient.

\section{Writing versus Design: Divisions of Labor}

Thus, all three of these women were able to leverage their writing skills to communicate effectively and efficiently with their audiences and become recognized for their writing ability by peers, supervisors and/or instructors. However, being associated with writing ability also comes with risks for these women, especially concerning divisions of labor. Katy in particular found herself writing more often than her male peers. This time spent writing was not always accounted for or recognized officially as engineering labor. When labor is overlooked or dismissed, it risks being seen as separate from the work of a particular discourse community and therefore less valuable. In the case of engineering, design, research, and calculation are the forms of production acknowledged by the discipline. While writing can facilitate those activities, it can also be ignored in favor of blueprints, research results, and data. In addition, the split between the technical and the written reifies historical gender divisions. As Rossiter notes, in the 1940s and 1950s women in chemistry were often underutilized as researchers and were urged "to head for three sex-typed and often conflated areas: chemical librarianship, literature chemistry (including abstracting and often patent searching), and technical writing or journalism." ${ }^{33}$ While these positions required specialist knowledge, men dismissed "such 'desk work' as suited only to 'misfits' and held onto their laboratory jobs, which paid better anyhow." ${ }^{64}$ In fact, one justification for urging women into these positions was that women were seen as better suited for this kind of labor, ${ }^{65}$ an attitude that echoes the belief that women in the sciences tend to be better communicators.

Given the tacit hierarchies of labor in engineering and scientific disciplines, the belief that women are better writers and speakers is a dangerous one to hold unquestioned. It is especially problematic when so much of writing that occurs in these settings is invisible or at least secondary to the more tangible products produced, particularly through design or modeling. What gets held up as instances of engineering work are blueprints, design plans, results from experiments, and calculations rather than the writing that surrounds or facilitates those activities, such as reports and research articles. Christine acknowledged this attitude toward writing when she characterized research as the main goal and the writing as an "afterthought" because what is more central is the content or information than the writing itself:

It's almost like writing it up is almost an afterthought for us [...]. But from our standpoint, we will have models and code and data and tables and analysis, and this body of work that's like this and now we're like, how do we get this into a 10 or 15 or whatever page paper [...]. So it's rare that

\footnotetext{
6125 August 2014

${ }^{62}$ Frost, “Apparent Feminism as a Methodology for Technical Communication and Rhetoric,” 2016, p. 19.

${ }^{63}$ Rossiter, Women Scientists in America, 1995, p. 261.

${ }^{64}$ Rossiter, Women Scientists in America, 1995, p. 262.

${ }^{65}$ Rossiter, Women Scientists in America, 1995, p. 264.
} 
This is an author-produced, peer-reviewed version of this article. The final, definitive version of this document can be found online at Engineering Studies, published by Routledge. Copyright restrictions may apply. doi: 10.1080/19378629.2017.1397677

we're changing the world with what we're writing about—it's more there's some tables, or there's a new model, or it's the way we did the literature review [...]. The paper itself is just the vehicle to communicate the real contribution of what they're making. ${ }^{66}$

Even for a researcher who values writing and dedicates time to ensuring her communication is clear, writing becomes not a product that can stand on its own but rather the "vehicle," to use Christine's term, for the information she needed to communicate. Implicit in this distinction is that the knowledge and content is what is important, and that writing is just the means to the end. This distinction creates a hierarchy between the production of technical knowledge and the communication of that knowledge, one that values technical information over writing.

Katy remarked on this division of labor when she compared herself to her male peers, which replicates the division Rossiter examines, albeit more subtly. As the only woman engineer at her firm, she asserted that she was better at writing than most of the men she worked with, which she in part attributed to her willingness to spend more than the minimum time and space needed or her refusal to satisfice. However, she was also conscious that because her supervisors recognized her writing skills, she was frequently assigned more writing than the other male engineers. In one case, the firm was struggling to complete an operations and maintenance manual by a deadline, so they assigned sections out to several engineers. After Katy had completed her allotted sections, the assignments were shuffled, and she was required to write even more. Because she ended up writing so much more than anyone else on a project that she was not even officially a part of, Katy was frustrated both by her peers' failure to pull their weight and her supervisors' failure to recognize the significant amount of work she contributed. ${ }^{67}$

More to the point, Katy is aware that if she spends her time writing reports, she is less likely to be designing and calculating, the more highly valued and recognized forms of engineering production. She is also conscious that writing more means practicing design skills less:

I feel like I write more than I design, I'm losing those skills. So I don't practice as much design work whenever I'm spending a month writing a report. I mean I get some, to get the information in here, but I feel like I focus a lot of energy at something that's also presentable, and also probably more energy than some people that I know, like peers or people in my office, so that's the other thing that hinders. ${ }^{68}$

Because she values writing, Katy dedicates more time and energy on it than her peers, but that time means that she is assigned more writing and given less design work to do. Unlike the women Malone and Rossiter examine, ${ }^{69}$ Katy's case does not reveal an overt division of labor, yet the implications are troubling. Because Katy uses writing to assert herself as a competent professional, a strategy other engineering women are likely to employ, she runs the risk of being associated more with writing than the more visible design work valued by her discourse community.

What Katy experiences possibly begins at the university level, when engineers are becoming socialized to the conventions of professional practice. Emma's case illustrates this gendered division between writing and technical work. On a design team in one of her engineering courses containing two men and two women, the women became primarily responsible for the writing of the report. To make up for their lack of writing, the two men focused on calculating and building the project, a fish tank to test filtration design:

So I feel like boys more or less stick to, they more or less stuck to gathering the data with the fish tanks, you know, putting the fish tanks together. I mean, Casey [the other woman on the team] and I definitely did the drilling in the tanks and connecting the plumbing and what-not, but when it come [sic] to reports, it was definitely more Casey and I working on it. Andrew did help at the very, he did start helping more after he saw how much Casey edited from his paragraphs. ${ }^{70}$

Emma was also quick to point out that this division was not necessarily due to gender but because she and Casey spent more time together, commenting that "I don't think it was mainly because of the gender gap, it was just timing-wise, Casey and I had more time to spend together because she, we had more classes together [...] and the boys had separate classes from us, so it was really hard to get on the same time schedule." ${ }^{71}$ In addition, project roles were never

\footnotetext{
${ }^{66} 23$ June 2014.

${ }^{67} 17$ December 2014.

${ }^{68} 17$ December 2014.

${ }^{69}$ Malone, “Chrysler’s Most Beautiful Engineer,” 2010; Rossiter, Women Scientists in America, 1995.

${ }^{70} 16$ December 2014.

${ }^{71} 16$ December 2014.
} 
This is an author-produced, peer-reviewed version of this article. The final, definitive version of this document can be found online at Engineering Studies, published by Routledge. Copyright restrictions may apply. doi: 10.1080/19378629.2017.1397677

negotiated but occurred somewhat naturally: "I feel like it just kind of happened. We never negotiated it, we were just at that point where you just go and check the tank when you get to class, and it just seemed that Nishawn was always checking the tank, like he got there early or something."72 Because it seemed that everyone was contributing as best they could in their own way, Emma did not seem concerned that she and Casey had completed the bulk of the writing labor.

While Emma felt that her team worked productively together, the writing the men did contribute raised concerns in terms of quality and appropriateness. Both men's writing required significant revision and editing to make it acceptable:

When each person came to the table, it wasn't done or it was really poorly done, like they didn't pre-edit it before they gave it to us, and so, um, I'm a person who believes wholeheartedly in editing. I don't believe you can write something and it's going to be perfect, you need to edit it. And so things didn't make sense, there wasn't even complete sentences, like they wrote down their thoughts as though they were brainstorming, like that's all they gave us was brainstorming. ${ }^{73}$

Emma commented that both writers expressed a lack of confidence, one because he misunderstood what was required and was taken aback by the amount of editing Emma and Casey did to his writing, and the other because he was a multilingual writer who felt less confident in his writing. It is possible that the men found other ways to contribute because they wanted to avoid the writing work that they felt less capable of performing adequately. Thus, unconsciously or consciously, the men adopted a strategy of writing avoidance that was overlooked in the final project.

While not necessarily intentional, Emma's experience reflected a gendered division of labor, where the two women on the team produced the writing while the two men did more technical work. That work was somewhat evenly distributed, with each member contributing toward the final goal, yet the gendered division between written and technical work is problematic. Here, the women took on more of the written, yet invisible, labor. Meanwhile, the men were responsible for the technical labor that is more visible in terms of both a product (the fish tank) and the numbers produced from measurements. While Emma did not believe that the division was based on gender-instead, it was because the women were more skilled with the writing and the timing worked out for the women to work togetherthe division of labor reveals how women are associated with writing in engineering settings, even at the schooling level. The men on the team never had an opportunity to improve their writing, and the women are potentially denied opportunities to hone technical skills. Furthermore, the division of labor Emma describes reflects the situation many women encounter in the profession, where historically writing is seen as women's work, women are assigned more writing-based tasks, and women are viewed as having more developed writing skills by both themselves and their peers.

Research on the value of writing in collaborative projects also demonstrates a gendered division of labor. Wolfe and Alexander found in their study of mixed-gender teams that men assumed control of the computer aspects of a project and women became more responsible for the writing. ${ }^{74}$ This gendered division of labor was not problematic until they examined how each type of contribution was valued. Even if the writing components took more time, the technical labor was more highly valued. In fact, writing itself was rendered somewhat invisible compared to more prestigious computer work. Wolfe and Alexander point out that "In two of the groups we observed, the male computer experts contributed no substantive writing to the group project. In fact, these two men Brandon (Team 2) and Geoff (Team 7) seemed to perceive computer work as a way to avoid writing." 75 Their conclusions indicate that "some team members tended to overlook or minimize women's written contributions while simultaneously praising the quality of men's writing even though those men had not produced any independent writing for the project." 76 As stated in the quotations above, both Katy and Christine noted that writing was subordinate to the technical, design work, even though they valued it.

Wolfe and Alexander's findings provide a problematic lens to view Emma's experience working on a team. While Emma was satisfied with her collaborative project, the ways that writing more "naturally" fell to the women are troubling. In classroom settings, if women are denied access to practicing technical skills, they may not gain as much

\footnotetext{
7216 December 2014.

7316 December 2014.

${ }^{74}$ Wolfe and Alexander, “The Computer Expert in Mixed-Gendered Collaborative Writing Groups,” 2005.

${ }^{75}$ Wolfe and Alexander, “The Computer Expert in Mixed-Gendered Collaborative Writing Groups,” 2005 , p. 147.

${ }^{76}$ Wolfe and Alexander, “The Computer Expert in Mixed-Gendered Collaborative Writing Groups,” 2005, p. 162.
} 
This is an author-produced, peer-reviewed version of this article. The final, definitive version of this document can be found online at Engineering Studies, published by Routledge. Copyright restrictions may apply. doi: 10.1080/19378629.2017.1397677

experience as their male peers. Wolfe and Alexander demonstrate that writing may not be as highly valued as technical knowledge; furthermore, they found that the men who claimed expert status with computers often withheld that knowledge from their female classmates. ${ }^{77}$ Finally, this division also allows male students to avoid writing and to fail to develop writing skills they need, and they reap the rewards of higher grades when paired with competent female writers who are also women. The gendered division of labor thus has troubling implications in continuing to reify the association of writing as women's work and its more invisible, less prestigious status in engineering. As students, women are socialized into a system that divides work into the written versus the technical and places the burden of communication on women. If they encounter this division as students, they may be less likely to question that binary when they move into the workplace.

\section{Double-Binds in Women's Communication}

In addition to taking up more of the writing labor, Katy, Christine, and Emma each perceived their writing as different from that of their male peers. Each woman's writing was also viewed as different, especially in terms of length and style. As with the division of labor, these perceptions can have troubling implications. For these women, their knowledge of when it was essential to say more on a particular topic was rooted in their considerations of the audience's needs. Yet for a woman, going into more detail runs the risk of being seen as verbose and as not valuing the core principle of efficiency in technical writing, even though efficiency should account for quality and impact as much as economy, using Frost's rearticulation. When paired with associations of women as "chatty," or as not capable of being silent, and men as terse, women's tendency to include more description raises issues of how their gender may affect a reader's reception of their work.

Katy's case best demonstrates the potential double-bind that offering detail can place a woman engineer: if she does not write enough to accomplish her purpose, she may be seen as incompetent, but if she writes too much, she may be perceived as chatty and as not adhering to the norms of engineering discourse. For instance, Katy's mentor and direct supervisor remarked, "she is going to have to write a facility plan for [Woodsville] [...] I hope she's short and to the point and not verbose, if you know what I mean." ${ }^{78}$ While he praised her ability to write clearly and effectively overall, his comment raises concerns that she would write more than might be acceptable, even if she has legitimate reasons for doing so. And being verbose instead of concise would indicate that she does not write efficiently, as the values of the engineering discourse community demand. The company's president also noted that the level of detail Katy provides is not strictly necessary for the work she needs to do. He was also careful to point out that she was never viewed as "talking down to anybody," "9 which is one way including substantial description could be perceived. In addition, he mentioned that her level of description never seemed to be ill-received by clients. While he was careful to focus on praising her writing, these comments reveal a belief that writing more descriptively can have negative ramifications for an engineering writer, especially when women are seen as unable to get to the point. It also indicates a more limited view of efficiency in failing to recognize where detail can lead to efficient and more effective communication.

More tellingly in terms of gendered perceptions of communication, two of Katy's coworkers indicated that she occasionally had difficulties communicating. While her coworkers were careful to note that Katy was a highly skilled engineer, the gendered implications of these criticisms are worth teasing out. First is the fact that her mentor raised the possibility that she had trouble communicating with contractors for a variety of reasons. As Katy herself notes, as a civil engineer with active projects, she interacts with primarily male contractors who are often hostile to the presence of women. One of the problems with working in a field such as construction, as Katy comments, "is working in the field with jackasses who are sexist." ${ }^{80}$ She continues, "Being told that women are hard to work with in construction because we are emotional is really demeaning. [...] that comment [about women as emotional and irrational] would never have been made if it was just a man to a man, a man to another man." ${ }^{81}$ As a woman working in a profession not only dominated by men, but within a highly masculine culture that entails working with other male-dominated fields such as construction, Katy is aware that her sex might create some problems in the field because men may be

\footnotetext{
${ }^{77}$ Wolfe and Alexander, “The Computer Expert in Mixed-Gendered Collaborative Writing Groups,” 2005, p. 150.

${ }^{78} 26$ February 2014.

${ }^{79} 18$ February 2014.

${ }^{80} 17$ December 2014.

${ }^{81} 17$ December 2014.
} 
This is an author-produced, peer-reviewed version of this article. The final, definitive version of this document can be found online at Engineering Studies, published by Routledge. Copyright restrictions may apply. doi: 10.1080/19378629.2017.1397677

unwilling to work with her or other women. It is difficult to ignore Katy's gendered interactions with contractors and individuals like them or the experiences of other women engineers venturing into a domain that is often subtly or even actively hostile to women. ${ }^{82}$

Some of this perceived difficulty seemed related to Katy’s communication style, at least for her coworkers. In fact, two of her coworkers referred to her as "blunt" when asked about ways she might struggle as an engineer. This particular term, and how it was used, indicates a conflict between perceptions of how Katy should communicate as a woman and the effective communicative strategies she had to employ as an engineer. Katy is frequently direct and does not hesitate to share her viewpoints, especially when she sees an issue or problem. In engineering, this directness is valued - but in a woman is seen as potentially problematic. For instance, the president of the company remarked:

In some cases, [Katy] can be a little blunt. She has never been blunt in a manner that would cause offense to our clients, but she will definitely tell you what she thinks. And this is not a bad, I'm not—she is a very straightforward person when it comes to conveying her opinion and technical aspects of any job, and she makes sure the client and anyone else knows exactly what they need to know. It's refreshing, in any case, to many people. The only drawback is that she can be a little blunt. ${ }^{83}$

Another coworker also called attention to this trait, noting that she would refuse to let an argument or subject go when she knew that she was right, and he also referred to the way she communicated as "blunt." ${ }^{84}$ Both tried to couch the comment as simply a less-positive attribute, especially as it was in response to a question about Katy's weaknesses. Yet the fact that two separate individuals both made note of this particular characteristic using the same term is telling. One reason this word "blunt" is problematic is the double-meaning behind it: it is not a characteristic typical of the ways women communicate-stereotypically, women are not blunt; they soften their criticisms and often couch their comments in more positive terms. ${ }^{85}$ Wolfe and Powell examine the effects of gendered perceptions of communication in engineering teams, finding that speech acts that were more typically feminine were punished by male participants. ${ }^{86}$ One of their findings demonstrated that engineering men perceive female-typical speech as weaker or as expressing insecurity, such as women's tendency to phrase criticism using an "I-statement," a pattern viewed as weak. ${ }^{87}$ In this case, Katy is in another double-bind, where if she were less direct, her voice would be silenced, yet she risks censure for being so direct in her communication.

Katy, in her bluntness, is conforming to speech patterns more typical of engineering culture, yet less typical of women. Because she is so direct, she risks censure from those she talks to, and her coworkers find her directness to be potentially problematic. It is less likely that these two men would criticize a male coworker-someone who they know is highly intelligent and capable-if he were direct (or even blunt) in his communication. Katy comes to conclusions that are well-reasoned, and she often finds problems that others miss; if she were not so blunt, it is possible that her message would not be heard. In other words, if Katy were less direct with her speech, she would actually be viewed as less competent and potentially punished by having her recommendations ignored or overlooked. In this case, she is so capable that her so-called "bluntness" is raised only as a minor issue embedded within praise. Thus, while Katy is criticized for her directness, she must speak in both engineering-typical and male-typical ways to be seen as fully capable and as a member of her discourse community.

Unlike Katy, who was forthcoming about the sexism she had experienced in the workplace and some of the ways her gender directly affected communication, Christine tended to gloss over potential impacts. While reluctant to comment on the ways her communication may have been subject to gendered perceptions, Christine's responses revealed that she had concerns related to those perceptions as she navigated her workplace environment, particularly as a mother and academic:

I'm not as close to these things as you can tell [...] but I do think there are women-I do know peers at other institutions where you feel like there's a situation where people are just not as supportive or where they do still have the sort of a faculty member who's not really aware of a flexible schedule, or someone is sick, then you have to come with another plan for class. Which is kind of the worst

\footnotetext{
${ }^{82}$ Yates, "Retention of Nontraditional Engineering Construction Professionals," 2001, pp. 42-45.

${ }^{83} 18$ February 2014.

${ }^{84} 7$ March 2014.

${ }^{85}$ Wolfe and Powell, "Biases in Interpersonal Communication,” 2009, pp. 8-11.

${ }^{86}$ Wolfe and Powell, "Biases in Interpersonal Communication,” 2009, pp. 8-11.

${ }^{87}$ Wolfe and Powell, "Biases in Interpersonal Communication,” 2009, pp. 10-11.
} 
This is an author-produced, peer-reviewed version of this article. The final, definitive version of this document can be found online at Engineering Studies, published by Routledge. Copyright restrictions may apply. doi: 10.1080/19378629.2017.1397677

thing. The worst thing that happens is that your child is sick on a day you're supposed to be in class. Other than that you can pretty much move everything else. You just do the best you can to make sure that doesn't affect anything. ${ }^{88}$

Here, Christine notes that while academics may ostensibly have flexible schedules, she also realizes that the academic work environment can impact a parent, whether it is not having support from peers or supervisors, or the faculty member being unable to take advantage of the flexibility in scheduling to care for family. Her attitude, ultimately, is that one has to "make sure that it doesn't affect anything," which shifts the focus back to the individual, rather than the institution. As she noted earlier in the interview, she was fortunate to not necessarily have experienced bias, though she remarked that she experienced "some odd situations, but nothing that I wasn't able to deal with myself or go talk to someone about." ${ }^{89}$ Her focus in the interview, however, was not on those "odd situations" but rather on her individual choices. She also made sure to emphasize that

If there were metrics to achieve, I have achieved them. So whatever promotions and such came, I worked very hard that my gender was a non-issue. I had met all of the hurdles I needed to. It would have been very hard to make a case against my success. Because you do probably feel a little bit in my position like you have something to prove. To show that you can have four kids if you choose and still be successful in a traditional faculty position. ${ }^{90}$

While Christine felt supported—she had one child in graduate school, one pre-tenure, and two before her promotion to full professor - she also indicated that she recognized how her gender and decision to have children may have subjected her to gendered perceptions. Because of that potential, Christine did everything she could do as an individual to minimize their impact, including using her writing to meet the metrics needed for success and navigating workplace communication situations professionally.

That focus on her actions as an individual rather than problems in the institution meant that she carefully governed her appearance and workplace interactions, including separating her personal from her professional life.

I read a lot of books where people are in environments that aren't supportive, and students have come to me and have had odd experiences on internships where they really were in not great situations or didn’t feel like they were being taken seriously. I try to be pretty conservative. I mean, I'm not going to walk in here in a low-cut blouse and expect that people aren't going to notice that. I mean, I try to be very professional at work, and I'm really careful with my relationships with students and faculty-it's just very professional. I don't cross the line. I don't who's getting engaged. I don’t know who has a cat. I mean, I think in some ways I try very hard to, because some people kind of assume, "oh you're a mom. You're the mom, they love you because you're so motherly-like.” I try very hard to not have that experience. I mean, if I have a student who is having a serious problem, of course I will help them. But I'm not, I don't seek that. I don't try to become the mom or become the buddy. I try to stick sort of with a very professional relationship. ${ }^{91}$

In response to my follow-up question about separating her personal from professional life, Christine responded:

I do have, I would say I have some faculty who are friends. I teach Sunday school and work with girl scouts and I am a very caring person in that environment [...] I try not to cross that line at all. ${ }^{92}$

Because Christine is a mother, she indicates that she felt pressure to be the "motherly" type in her professional life, but she actively resisted that perception because it could interfere with her ability to be successful. She identified as someone who was caring and motherly in her personal life and volunteer work, but in the workplace, she minimized the chances that she would be perceived as anything other than serious and professional. Christine's belief that if she was seen as "the mom" or "the buddy" then she would not be able to be as successful or be taken as seriously demonstrates the quandary that she navigated daily. One aspect of her identity was as a woman and as a mother, but that identity was not present in the workplace so that she could assert the professional, serious academic persona.

\footnotetext{
${ }^{88} 26$ January 2015.

8926 January 2015.

${ }^{90} 26$ January 2015.

9126 January 2015.

${ }^{92} 26$ January 2015.
} 
This is an author-produced, peer-reviewed version of this article. The final, definitive version of this document can be found online at Engineering Studies, published by Routledge. Copyright restrictions may apply. doi: 10.1080/19378629.2017.1397677

For Emma, the biological engineering student, gendered perceptions of communicative practices took the form of her unease with her own feelings, a discomfort she attributed to the ways that engineering as a field punished women who are overly emotional. As part of her study abroad experience, she was asked to write a blog, a genre that was new to her and one that made her anxious. The source of her anxiety was that she knew that she should do more than simply record what happened to her. She understood that the genre of the blog post needed

to be much more inspirational writing. And it's going to be like a diary in a sense because you're going to explain how this experience changed you or what you felt. I guess do more feelings. I think that's going to be the basis of the writing, is that you write your feelings out. ${ }^{93}$

As she conveyed these ideas, each time she said the word feelings, it was enunciated strangely, almost with a wince, which made me ask, "What's making you uncomfortable about talking about your feelings?" Emma's reply pinpointed the trouble with being a woman in engineering: often, the culture requires a woman to deny a part of herself.

I think it's just funny, you know, when they tell you, you need to write your experience and get all your feelings out so you never forget it and stuff. And for me, feelings have never been-the quality desired by a female scientist or engineer especially. You need to be, like, like-So when I get upset, I start to cry. [...] And I hate that. I hate it so much. Because I was in the middle of Statics, trying to fight to get a freakin' A in the class, and he was telling me that I didn't work hard enough, and I walk away and I get tears in my eyes, and I'm like "oh crap, it's coming." And people were looking at me because it's mainly a male-dominated world, it's a very competitive classroom environment. It's really embarrassing to show emotions and to show you care for something like that. And it wasn't the fact that I was really upset I didn't get an A, it was the humiliation because, you know, I'm a girl and I cry. I get emotional. And I hate getting blamed for your emotions because you're a girl. It's like "no, I have emotions because I'm a human being." ${ }^{4}$

Her final response- “I have emotions because I'm a human being”-reveals the potential dangers of writing and communicating for women within an overtly masculine engineering culture. Emma understands that the masculine world that she has entered will punish her for feminized ways of writing and behaving. And that understanding has affected not only her ability to think about writing out her feelings, but also her capacity to experience her own emotional responses without being judged.

\section{Implications for Women Writers}

Thus, while writing might offer an avenue to women's success in engineering, it also exposes potential problems. If their writing is characterized as "chatty," women risk marginalization if they are perceived as communicating contrary to the values of the field. Equally problematically, direct forms of communication are punished even though the communicator is operating within the conventions of her discourse community. Since engineering prizes concision and directness in communication, the stereotype that women are verbose, prosy, or simply not male could lead their writing to be viewed as inconsistent with the field's values, especially when it comes to efficiency. And in Katy's case, her communication is both blunt and descriptive, placing her in two double-binds that she may not be able to escape.

Furthermore, as Emma demonstrates, some women may feel unable to access certain forms of communication because they are afraid of being too associated with their gender. While emotion or description do not belong solely to women, the cultural associations between emotion or "chatty" behavior and women's ways of writing risks overlooking the use of these strategies to communicate more effectively and efficiently. As Katy, Christine, and Emma all indicate, they write more because they understand the reader will potentially need more information, in line with the expanded definition of efficiency that Frost advocates. ${ }^{95}$ And as Emma shows, her discomfort with expressing herself is a direct result of being in a field that rejects emotion and forces her to deny her own experience as a woman. To disrupt these binaries and embrace a broader understanding of efficiency, engineering professionals must understand the range of forms efficiency can take and be conscious of the impacts of viewing women's communication in gendered ways.

\footnotetext{
9316 December 2014. Emma herself emphasized “feelings," as indicated with italics.

${ }^{94} 16$ December 2014.

${ }^{95}$ Frost, “Apparent Feminism as a Methodology for Technical Communication and Rhetoric,” 2016.
} 
This is an author-produced, peer-reviewed version of this article. The final, definitive version of this document can be found online at Engineering Studies, published by Routledge. Copyright restrictions may apply. doi: 10.1080/19378629.2017.1397677

In order to change the culture, engineering organizations can begin by acknowledging the sex-based divisions that continue to exist in who writes and how writing is perceived as gendered. For instance, in engineering classrooms, instructors who understand that women tend to write more frequently than men can make both male and female students conscious of this tendency. The instructor's articulation of these realities would work to reduce gendered divisions of labor that reinforce the implicit hierarchy in what is valued. Instructors can also make explicit a more nuanced definition of efficiency that recognizes and values audience awareness and the effective use of detail to communicate, rewarding writers who refuse to satisfice. In professional settings and industry, those writers (both male and female) who have been made more conscious of efficiency as accounting for more than energy expended can push against perceptions of communication that disadvantage women and place them in double binds. Acknowledging women's contributions through writing will also allow supervisors to disrupt the continued binary between writing and technical labor, demonstrating the value of writing within engineering practice. Finally, as engineering organizations continue to grow aware of the microaggressions and biases that disproportionally affect women, they can also begin seeing the ways masculine perceptions of women's communication contribute to the subtle biases that deny women's contributions and alienate them from the engineering community. Conscious awareness of these tendencies and the ways writing is subject to gendered perceptions is a first step in changing the overall culture.

While women's gendered experiences certainly interact with their identities as writers, it is dangerous to characterize their writing as gendered. As long as these cultural associations exist, women will have to guard themselves against gendered perceptions of their written work and thus their selves and their experiences. Calling these associations to light and demonstrating how women continue to write in discipline-appropriate ways will enable to them to resist gendered constructions of their work and make space for a broader understanding of what constitutes both engineering labor and efficiency. Instead of reading their writing as women's writing, their supervisors, instructors, and peers must consider the many factors at work and resist attempts to place restrictive frames around the engaging, effective, and appropriately descriptive work these women offer.

\section{References}

Annas, Pamela J. "Style as Politics: A Feminist Approach to the Teaching of Writing." In Feminism and Composition: A Critical Sourcebook, edited by Gesa E. Kirsch, Faye Spencer Maor, Lance Massey, Lee Nickoson-Massey, and Mary P. Sheridan-Rabideau, 61-72. Boston: Bedford/St. Martin’s, 2003.

Bix, Amy S. Girls coming to tech! A history of American engineering education for women. Cambridge, MA: The MIT Press, 2013.

Callahan, Janet, and Marcia Belcheir. "Testing Our Assumptions: The Role of the First Course Grade and Course Level in Mathematics and English.” Journal of College Student Retention: Research, Theory, and Practice 19, no. 2 (2017): 161-175.

Charney, Davida, John H. Newman, and Mike Palmquist. “'I’m Just No Good at Writing’: Epistemological Style and Attitudes toward Writing.” Written Communication 12, no. 3 (1995): 298-329.

Connors, Robert J. "The Rise of Technical Writing Instruction in America.” Journal of Technical Writing and Communication 12, no. 4 (1982): 329-352.

Flower, Linda. "Writer-Based Prose: A Cognitive Basis for Problems in Writing.” College English 41, no.1 (1979): 19-37.

Flynn, Elizabeth A. “Composing as a Woman.” College Composition and Communication 39, no.4 (1988): 423-435. Flynn, Elizabeth A. “Gender and Reading.” College English 45, no.3 (1983): 236-253.

Frost, Erin A. "Apparent Feminism as a Methodology for Technical Communication and Rhetoric.” Journal of Business and Technical Communication 30, no. 1 (2016): 3-28.

Haswell, Janis T., and Richard H. Haswell. "Gendership and the Miswriting of Students.” College Composition and Communication 46, no. 2 (1995): 223-254.

Haswell, Richard H., and Janis T. Haswell. "Gender Bias and Critique of Student Writing.” Assessing Writing 3, no. 1 (1996): 31-83.

Hiatt, Mary P. “The Feminine Style: Theory and Fact.” In Feminism and Composition: A Critical Sourcebook, edited by Gesa E. Kirsch, Faye Spencer Maor, Lance Massey, Lee Nickoson-Massey, and Mary P. Sheridan-Rabideau, 43-60. Boston: Bedford/St. Martin's, 2003.

Kramer, Andrea S. and Alton B. Harris. Breaking Through Bias: Communication Techniques for Women to Succeed at Work. New York: Bibliomotion, 2016. 
This is an author-produced, peer-reviewed version of this article. The final, definitive version of this document can be found online at Engineering Studies, published by Routledge. Copyright restrictions may apply. doi: 10.1080/19378629.2017.1397677

Layne, Margaret, ed. Women in Engineering: Professional Life. Reston, VA: American Society of Civil Engineers Press, 2009.

Leydens, Jon A. "Novice and Insider Perspectives on Academic and Workplace Writing: Toward a Continuum of Rhetorical Awareness. IEEE Transactions on Professional Communication 51, no. 3 (2008): 242-263

Longo, Bernadette. Spurious Coin: A History of Science, Management, and Technical Writing. Albany, NY: State University of New York P, 2000.

Mallette, Jennifer C. “Writing and Women’s Retention in Engineering.” Journal of Business and Technical Communication 31, no. 4 (2017): 417-442.

Malone, Edward A. “Chrysler's 'Most Beautiful Engineer': Lucille J. Pieti in the Pillory of Fame.” Technical Communication Quarterly 19, no. 2 (2010): 144-183.

Malone, Edward A. "Women Organizers of the First Professional Associations in Technical Communication." Technical Communication Quarterly 24, no. 2 (2015): 121-146.

Poe, Mya, Neal Learner, and Jennifer Craig. Learning to Communicate in Science and Engineering. Cambridge: The MIT Press, 2010.

Ritchie, Joy S. “Confronting the ‘Essential’ Problem: Reconnecting Feminist Theory and Pedagogy.” In Feminism and Composition: A Critical Sourcebook, edited by Gesa E. Kirsch, Faye Spencer Maor, Lance Massey, Lee Nickoson-Massey, and Mary P. Sheridan-Rabideau, 79-102. Boston: Bedford/St. Martin’s, 2003.

Ritchie, Joy S., and Kathleen Boardman. “Feminism in Composition: Inclusion, Metonymy, and Disruption.” In Feminism and Composition: A Critical Sourcebook, edited by Gesa E. Kirsch, Faye Spencer Maor, Lance Massey, Lee Nickoson-Massey, and Mary P. Sheridan-Rabideau, 7-26. Boston: Bedford/St. Martin’s, 2003.

Rossiter, Margaret W. Women Scientists in America. Baltimore: Johns Hopkins University Press, 1995.

Simon, Herbert A. The Sciences of the Artificial. Cambridge: The MIT Press, 1969.

Sommers, Nancy. "Revision Strategies of Student Writers and Experienced Adult Writers." College Composition and Communication 31, no. 4 (1980): 378-388.

Winsor, Dorothy A. Writing like an Engineer. Mahwah, NJ: Lawrence Erlbaum, 1996.

Winsor Dorothy A. Writing Power: Communication within an Engineering Center. Albany: State University of New York Press, 2003.

Watts, Ruth. Women in Science: A Social and Cultural History. New York: Routledge, 2007.

Wolfe, Joanna. "Meeting Minutes as a Rhetorical Genre: Discrepancies Between Professional Writing Textbooks and Workplace Practice.” IEEE Transactions on Professional Communication, 49, no. 4 (2006): 354-364.

Wolfe, Joanna and Kara Poe Alexander "The Computer Expert in Mixed-Gendered Collaborative Writing Groups." Journal of Business and Technical Communication 19, no. 2 (2005): 135-170.

Wolfe, Joanna and Elizabeth Powell. "Biases in Interpersonal Communication: How Engineering Students Perceive Gender Typical Speech Acts in Teamwork. Journal of Engineering Education 98, no. 1 (2009): 5-16.

Yates, J.K. "Retention of Nontraditional Engineering Construction Professionals." Journal of Management in Engineering 17, no. 1 (2001): 41-48.

Yin, Robert K. Case Study Research: Design and Methods. $4^{\text {th }}$ ed. Thousand Oaks: Sage Publications, 2009.

Yin, Robert K. Applications of Case Study Research. $3^{\text {rd }}$ ed. Thousand Oaks: Sage Publications, 2012. 